Philosophie ANTIQUE
Philosophie antique

Problèmes, Renaissances, Usages

$18 \mid 2018$

L'athéisme antique

\title{
Theomachy and Theology in Early Greek Myth
}

The Case of the Aeolids

\section{Tim Whitmarsh}

\section{(2) OpenEdition}

Journals

Electronic version

URL: https://journals.openedition.org/philosant/995

DOI: $10.4000 /$ philosant.995

ISSN: 2648-2789

Publisher

Éditions Vrin

\section{Printed version}

Date of publication: 1 November 2018

Number of pages: $13-36$

ISBN: 978-2-7574-2372-1

ISSN: 1634-4561

\section{Electronic reference}

Tim Whitmarsh, "Theomachy and Theology in Early Greek Myth ", Philosophie antique [Online], 18

2018, Online since 01 November 2019, connection on 04 December 2022. URL: http://

journals.openedition.org/philosant/995 ; DOI: https://doi.org/10.4000/philosant.995

\section{(c) (i) (3)}

Creative Commons - Attribution-NonCommercial-NoDerivatives 4.0 International - CC BY-NC-ND 4.0 https://creativecommons.org/licenses/by-nc-nd/4.0/ 


\title{
THEOMACHY AND THEOLOGY IN EARLY GREEK MYTH The Case of the Aeolids \\ Tim WHITMARSH \\ University of Cambridge / University of Pretoria
}

\begin{abstract}
RÉSUMÉ. Cet article se penche sur la représentation de la famille des Éolides dans le Catalogue des femmes du pseudo-Hésiode. Les Éolides, qui apparaissent très tôt dans le cycle mythique (et de façon particulièrement proche de la phase originelle de la vie humaine dans laquelle dieux et mortels ont été convives), présentent un cas remarquable de jalousie du divin. Ils cherchent en particulier à rivaliser avec la divinité en faisant usage d'artefacts humains : le langage, l'artisanat, le spectacle. Cette emphase sur l'artificiel implique la croyance, parmi certains d'entre les Éolides (croyance qui cependant n'est pas à première vue assumée par le poème) que la divinité peut être elle-même considérée comme une invention humaine. On peut contextualiser cette croyance en la comparant aux forces culturelles de créativité technologique plus vastes à la période archaïque, en particulier au développement des représentations artistiques des dieux.
\end{abstract}

SUMMARY. This article considers the representation of the Aeolid family in the pseudo-Hesiodic Catalogue of Women. The Aeolids, who come early in the mythical cycle (and thus particularly close to the original phase in human life when gods and mortals dined together), display a strong case of divine envy. In particular, they seek to emulate divinity using human constructions: language, manufacture and performance. This emphasis on constructedness implies a belief among some of the Aeolids (a belief that is, however, not prima facie endorsed by the poem) that divinity can be thought of as a human invention. This belief can be contextualised in terms of wider cultural forces of technological creativity current in the archaic period, in particular the development of artistic representations of the gods.

Philosophie antique, $\mathrm{n}^{\circ} 18$ (2018), 13-36 



\section{Theomachic myth and 'theology'}

In memoriam M. L. West

In this article ${ }^{1}$ I explore the 'theological' implications of a set of archaic Greek stories associated with one particular mythical family, the descendants of Aeolus. ${ }^{2}$ In invoking 'theology' I do not mean, of course, to imply that polytheistic Greek myth pretends to the metaphysical coherence that was attributed to Christianity by the Church Fathers. My points are, rather, three. First, myth carries with it a set of metaphysical assumptions about the rules according to which the cosmos operates. The second is that these assumptions are specific to a particular culture at a particular period. The third is that every mythological telling represents a specific intervention in the necessarily complex set of questions relating to the divine.

Can archaic myth really be understood as a repository for metaphysical ideas? Initially, the answer might seem to be 'no'. Myth long predated the great intellectual revolutions first of Ionia and southern Italy and then of Athens, revolutions that generated reasoned discourse that the Greeks named $\varphi \imath \lambda 0 \sigma o \varphi$ í $\alpha$. Yet the abruptness of this transition is not to be taken for granted. The idea of a shift from an earlier, mythical 'mentality' to a later, 'philosophical' one is rooted in the specific concerns of the European Enlightenment, and is no longer tenable. ${ }^{3}$ Twentieth-century psychoanalysis did little to unsettle this view; indeed by associating myth with dreaming and the subconscious, psychoanalysis at one level merely underlined its 'non-rational' nature. Structuralism took a step forward, certainly, by insisting on the fundamental coherence of mythical thought, but it still tended

1. I am grateful for comments on this paper to those who have discussed its ideas in Oxford, Ann Arbor and Paris.

2. The term 'theology' has made a dramatic return to the field of classical studies: see esp. Versnel 2011 and Eidinow, Kindt and Osborne (eds.) 2016.

3. For an account and critique of this habit see Lloyd 1990. 
to present that coherence as different in kind from that of literate cultures: as mystified, as symbolic rather than rational. Vernant, for one, still spoke of a transition from mythos to logos. ${ }^{4}$ It is only recent anthropology that has decisively challenged this narrative: in particular, Philippe Descola and Eduardo Viveiros de Castro have insisted that all mythological systems have their own 'metaphysics', their own implicit postulates about the interrelated functionings of the universe and its constituent parts. ${ }^{5}$ It is following this school that I posit a metaphysical dimension to archaic mythology. The latter is, for sure, not conventionally philosophical in one respect, in that it is expressed through narrative rather than linear argumentation; but as we shall see, the Catalogue at any rate seems to participate in wider contemporary debates, aspects of which, indeed, are shared with Presocratic thinkers. ${ }^{6}$

The stories I shall discuss have to do with the phenomenon of 'theomachy', of humans pitting themselves against the divine realm - a stance

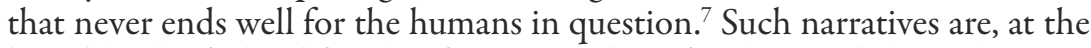
broad level, of a kind familiar from a number of archaic and classical genres, most notably Athenian tragedy. They are often understood by modern critics in straightforwardly moralistic terms: they teach us, it is alleged, through the ultimate punishment of the theomach, that it is wrong for mortals to overreach themselves and aim for the joy and/or knowledge that is proper to the gods alone. Theomachic narratives, in this light, are seen as normatively pietistic: 'In tragedy the positive values of piety were virtually unquestioned ... When characters challenged or violated them, their actions and attitudes required examination'. Theomachy thus becomes an expression of what is popularly (if inaccurately) referred to as tragic hubris, ${ }^{9}$ and its punishment a clear reassertion of the rectitude of conventional religious values.

4. E.g. Part 7 of Vernant 1983 is entitled 'From Myth to Reason'. For a recent refinement of the 'from mythos to logos' narrative (not, of course, Vernant's invention) see Fowler 2011; and for a critique see Yu 2017.

5. Descola 2013; Viveiros de Castro 2014.

6. In what follows I use the text of Most 2007 for the Catalogue ('Most'), cross-referenced to Merkelbach and West 1990 ('MW') - not to be confused with Merkelbach and West 1967, which lacks some crucial later papyrus publications.

7. The root $\theta \varepsilon o \mu \alpha \chi$ - is securely attested first in Euripides' Bacchae of $405 \mathrm{BCE}(45,325$, 1255), where it is used in this sense of Pentheus as one who resists Dionysus. It is also, however, used later in a different sense to refer to conflict between the gods, especially in relation to Iliad 21 (e.g. Plato R. 378d; Heraclitus All. 7.14; Sch. Hom. Il. 21.470).

8. Mikalson 1991: 162.

9. Fisher 1992 is a comprehensive study of the ancient conception of hubris, which counts among its aims the intention to 'demonstrate, once and for all, the fundamental flaws in what might be called the "traditional view (or views) of hybris", and to reveal the misconceptions and oversimplifications which these views imply of the conceptual relationships of many Greek terms, of the supposed activities of the gods, and of the patterns of "tragic" action and suffering' (1). Hybris is, rather, fundamentally an assault on the honour of another. 
This picture is, however, a simplification, based at least in part in Christian notions of sin. Greek religion certainly knew of order and transgression, and of mortal crime and divine punishment: the Odyssey is proof enough of that. But it had neither a unified moral code for humans to follow nor a robust belief in the infallibility of divine monitoring of and response to human ethics. I shall argue that the instances of theomachy that I consider are best understood not simply as straightforward theological protreptics (although they have an element of that), but as opportunities to experiment, in an exploratory mode, with different models of response to the phenomenon of divinity - including forms of scepticism that we might associate with 'atheism' (in the looser, extended sense employed by the ancient Greeks). ${ }^{10}$

\section{The Age of Commonality}

Aeolus, the progenitor of the Aeolids, is a significant personage, one of the sons of Deucalion's son Hellen, who was the first 'Hellene', and in the Greek mythical imaginary also the first human being born after the flood. He (Aeolus) was the eponymous ancestor of the Aeolians, the branch of the Greek ethnos that also gave its name to a dialect regionalised primarily in Thessaly, Boeotia and on the Anatolian coast. In the earliest stratum of Greek myth - with which we are concerned here - he is distinct from the lord of the winds, the son of Hippotes known from the Odyssey, who lived far from the Greek mainland, and would in post-Homeric times lend his name to the Aeolian isles north of Sicily. ${ }^{11}$

The stories about the first Aeolids - the descendants of our (Thessalian) Aeolus - are preserved in the Catalogue of Women, a now-fragmentary epic poem that was in antiquity usually (and probably erroneously) attributed to Hesiod, ${ }^{12}$ and which modern scholars have variously dated in the large range

10. On ancient disbelief and atheism see Decharme 1904; Drachmann 1922; Ley 1966; Dorival and Pralon (eds.) 2002; Cancik-Lindemaier 2006; Bremmer 2007; Sedley 2013a; Whitmarsh 2015. The Greek words atheos (attested from the fifth century BCE) and atheotes (second century BCE) cover a far wider range of sceptical stances than the English 'atheist' and 'atheism': the ambiguity in ancient terminology is noted at Diogenes Laertius 7.119 (reporting Stoic teaching).

11. The confusion between the two is irrelevant to the present discussion, but it is nevertheless early and problematic. The Hesiodic Catalogue gives the Thessalian five daughters and seven sons (fr. 10.25-34 Most = fr. 10a.25-34 M-W; on the identity of the seventh see below, n. 27; and on the 'seven sons' motif cross-culturally see West 1985: 28-9); Homer, meanwhile, gives the 'Tyrrhenian' six daughters and six sons, who live together in incestuous unions (Od. 0.1-9). In Euripides, Canace is apparently the daughter of the Tyrrhenian (Euripides $\operatorname{Tr} G F$ Kannicht, Aiolos, ii-ixb); in ps.-Apollodorus, however, who may follow the Hesiodic Catalogue, she is the daughter of the Thessalian (Bibliotheca 1.7.3).

12. West 1985: 128 suggests that it may be based on a lost Hesiodic original; see also Fowler 1999: 1. 
between the early seventh and the late sixth centuries. ${ }^{13}$ The exact date does not matter greatly to the present argument, but it will be important, in due course, to acknowledge that the worldview reflected here was forged during an era of rapid and substantial social, technological and aesthetic change; the poem, I shall argue, reflects the transformative nature of its wider environment. A later date, moreover, would make the Catalogue poet an approximate contemporary of Xenophanes, the earliest surviving Presocratic explicitly to confront conventional wisdom about anthropomorphic divinity. ${ }^{14}$

Stories about the earliest humans are inevitably stories about the relationship between humans and gods, for in the earliest times, in the mythical imagination, the two lived in close promixity. There are some hints in archaic poetry that humans are descended from deities: a number of hints suggest that archaic myth imagined them to be the offspring of Melian Nymphs and Giants. ${ }^{15}$ The Iliad and the Odyssey offer little help here, since the world described there is by and large a late one in the mythical cycle, in which even the phenomenon of demi-gods (the products of unions between gods and mortals) is relatively rare. The Odyssey, however, knows of the Phaeacians, who are said to be ankhitheoi, 'close to the gods' (Homer Od. 5.35, 19.279; cf. 7.205 , cited below), which ancient commentators understood to mean 'genetically related', but which Homer seems to have understood in the looser sense of a 'special relationship. ${ }^{16}$ As their king Alcinous reports, however, this proximal relationship is precarious, and not to be taken for granted:

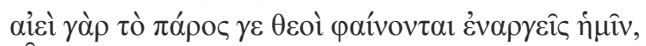

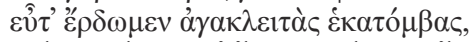

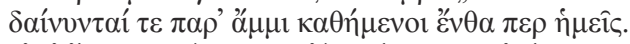

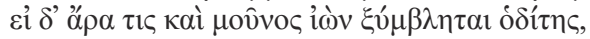

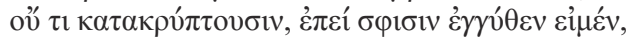

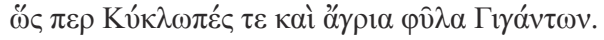

For always beforehand, at any rate, the gods have appeared before us in manifest form, whenever we sacrifice to them glorious hecatombs, and they feast among us, sitting where we sit.

And if one of us walking the roads alone meets them, they use no concealment, for we are near to them, as are the Cyclopes and the wild tribes of the Giants. (Od.7.201-206)

13. Janko 1982: 85-87 (cf. 200), for example, dates it to the early seventh century using linguistic criteria; West 1985: 130-137 to the mid-sixth century, on historical grounds. Hirschberger 2004: 45-51 surveys the arguments, tending towards the sixth century (but does not engage with Janko's data); see also Cingano 2009: 116-117.

14. For Xenophanes' comments on the gods see fr. D8-14 Laks-Most, and below.

15. Yates 2004.

16. Hainsworth 1988: 258. 
The gods' closeness to the Phaeacians is expressed through their commensality - food rituals being always a salient marker of identity in Homer $^{17}$ and through their avoidance of the human disguise that they normally adopt in connection with human beings (enarges is the regular Greek adjective that marks direct, epiphanic manifestation). But there is also a powerful implication that this is a special people whose specialness is slipping away from them. Alcinous' words show an awareness that his people's proximity to the divine is evanescent, set in a present that is already sloping into a past: although he uses the present tense to describe the gods' habits, he introduces the section

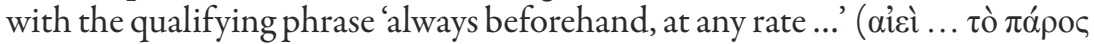
$\gamma \varepsilon$ ). Odysseus' arrival among the Phaeacians, indeed, marks the very end of their commonality with the gods - a conclusion that is set quite literally in stone once Poseidon has forbidden them to convey any more humans by sea, and petrified the ship that carried Odysseus. ${ }^{18}$ The poem thus positions itself on a temporal cusp, between the last vestiges of the age of commonality and the entirely mundane world that its audience knows.

The memory of a time when humans and gods lived in commonality also appears in Hesiod's Theogony, in a vexed passage. The story provides an aetiology of sacrifice as the primary medium of communication between humans and gods. During a common feast at Mekone, we read, the Titan Prometheus attempted to dupe Zeus by wrapping bones in fat: he thus inaugurated the practice of offering the inedible parts of the sacrificial victim to the gods, and saving the edible parts for humans. As Vernant has observed, this is a critical moment in the Greeks' myth-history, a moment when sacrifice was established as the primary mode of communication between gods and humans. ${ }^{19}$ What is important from our point of view is that this moment appears once again to mark the separation between gods and humans:

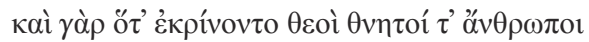

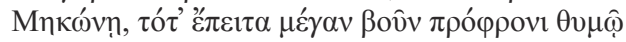

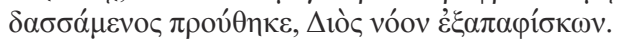

For when the gods and mortal men were being divided [?]

in Mecone, with eager spirit [Prometheus] divided up a great ox

and, trying to deceive Zeus' mind, set it before him.

(Th. 535-537)

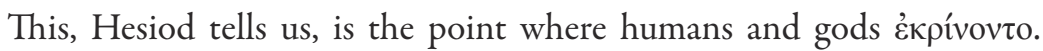
What does this word mean? Kpíveıv normally means 'to judge' or 'to distinguish'. Does it mean that mortals and gods 'were coming to a settlement', as Glenn Most (the Loeb translator) takes it ${ }^{20}$ Or, alternatively (as a scholiast

17. E.g. Vidal-Naquet 1970.

18. Homer $O d$. 13.146-182. On this Homeric theme in general see Ford 1992.

19. Vernant 1989. See also Clay 2003: 107-113.

20. Most 2007 ad loc. 
proposes) are we to take it that the nature of what it is to be a buman or a god was 'being judged' ? ${ }^{21} \mathrm{Or}$ is it, as the same scholiast proceeds to claim (even less plausibly), that a decision was being taken about which deities should be paired with which poleis? ${ }^{22}$ Most likely of all is that this is the moment when humans and gods 'were in the process of becoming separated'. ${ }^{23}$ This event would then mark a similar moment, in a different narrative mode, to the one where Odysseus arrives on Scheria: the conclusion, that is to say, of the era when gods and humans lived in common.

Homer and Hesiod present the age of commonality as defined by commensality. Humans, we are to infer, were still differentiated from gods by their mortality, but lived a life of ease with food provided for them. In the Catalogue of Women, however, commensality is additionally linked to sex and reproduction. The 'women' who are the subject of the catalogue are impregnated by gods, so as to produce the race of heroes. The proem, which survives in fragmentary form, explicitly links this erotic commingling with the motif of commonality of dining and political decision-making: ${ }^{24}$

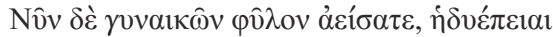

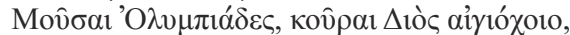

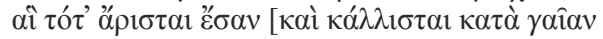

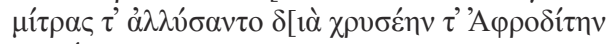

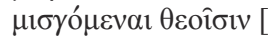

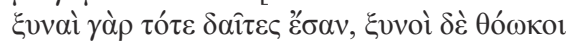

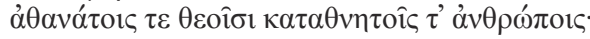

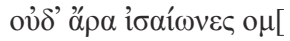

And now sing of the tribe of women, you sweet-voiced

Olympian Muses, daughters of aegis-holding Zeus -

those women who were the best at that time and most

beautiful on the earth,

and they loosened their girdles and because of golden

Aphrodite

mingling with gods $[\ldots]$ For at that time the feasts were in

common

and in common the councils for the immortal gods and for

mortal human beings;

and yet not equally long-lived [...]

(Catalogue of Women fr. 1.1-8 Most, MW; trans. adapted from Most 2007.)

Let us note particularly the particle yó $\rho$ in line 6, which indicates that the sexual union of gods and mortal women was logically dependent on the

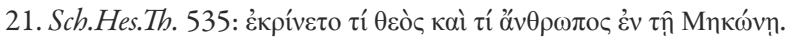

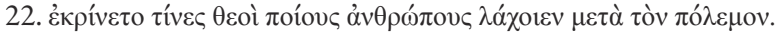

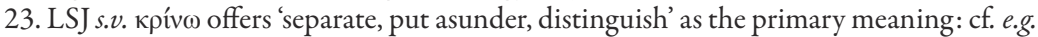

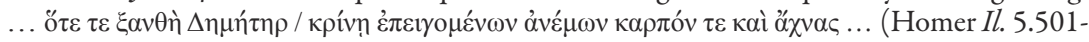
$502)$.

24. On the wider archaic context for this passage see Hirschberger 2004: 70-72. 
commonality of food and decision-making. This does not mean, of course, that gods cannot have sex with mortals without sharing a dinner or a political assembly. The poet's point is, rather, a different one: that the age in which sexual unions between gods and mortals was an era, now located categorically in the past ( $\tau$ ó $\tau \varepsilon)$, when sex was only one of a number of activities held in common between gods and humans.

Sexual reproduction, however, adds a different dimension, since it means that the offspring of the gods and mortals in the heroic age carry with them genetic traces of divine ancestry. In fact, the Catalogue presents humanity as a whole (at least as we understand it now) ${ }^{25}$ as genetically divine, since the first modern humans, Pyrrha and Deucalion, were the offspring of the Titans Epimetheus and Prometheus. The heroic race, then, results from the admixture of Olympian and human-Titan blood: it is this that makes heroes 'demigods' (i $\mu 1 \theta \dot{\varepsilon} \omega[v)$, a generic term that covers all of the heroes of the mythical age in general, whatever their actual parentage. ${ }^{26}$ The myth-historical structure of the Catalogue is designed to explicate heroic behaviour as rooted in divine ancestry, for which the age of commonality provides an aetiology regardless of the exact genealogy of individual cases.

\section{The Aeolids: envy towards the gods}

This sense that the earliest mortals were close, in several ways, to the gods will be significant for the argument that follows. Let us turn now to consider the specific case of the Aeolids, who seem to have had a particular difficulty letting go of the age of commonality. The Aeolids are given an unexpected prominence in the Catalogue, a prominence that has led some to hypothesise an Aeolian origin for the poem itself. ${ }^{27}$ Yet any suspicion of pro-Aeolian sentiment should be dispelled by a consideration of the criminality that seems to be genetically embedded in this people from the start. As it happens, we have the fragment introducing this family:

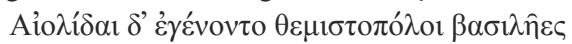

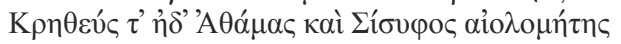

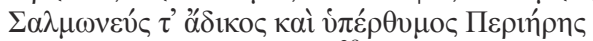

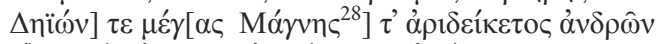

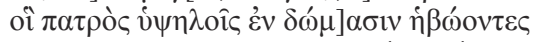

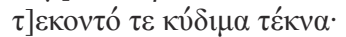

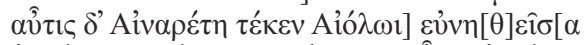

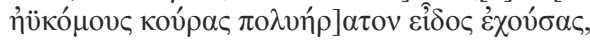

25. A previous race of humans was wiped out in the flood.

26. Cat. fr. 204.100 M-W = 155.100 Most.

27. Fowler 1999: 8-9.

28. Following Hirschberger 2004: 186, I have restored this name from ps.-Apollodorus Bibliotheca 1.7.3 (and Pausanias 6.21.7), despite the appearance of another Magnes at Cat. fr. 7-8 West, MW. Mínac, the other alternative, will not scan (the iota is short). 


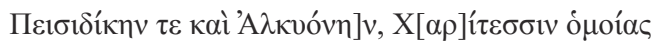

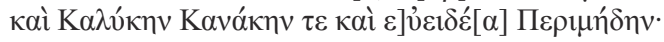

And sons of Aeolus were born, law-administering kings, Cretheus and Athamas and shifty-counseled Sisyphus; and unjust Salmoneus and high-spirited Perieres and great Deion] and [Magnes] celebrated among men who, in their father's lofty houses, when adolescents ... ... and they bore famous children.

Again, to Aeolus Aenarete,] bedded with him, bore beautiful-haired maidens] who had a [very] lovely form, Peisidice and Alcyone,] similar to the Graces, and Calyce and Canace and] fair-formed Perimede.

(Hesiod, Cat. fr. 10.25-34 Most = fr. 10a.25-34 MW; trans. adapted from Most 2007.)

Although $\theta \varepsilon \mu 1 \sigma \tau o \pi$ ó 0 ('law-administering') seems a positive epithet

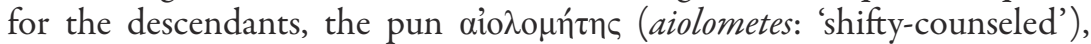
used of Sisyphus in the second line of this passage, locates a 'shifty' (aiolos) quality already in the founder. And in fact this is not a happy lineage. Cretheus and Athamas, certainly, are accorded no adjectives by the Catalogue poet; but while the first was unremarkable himself except for founding Iolcus, the second was a killer and the subject of fifth-century tragedies. ${ }^{29}$

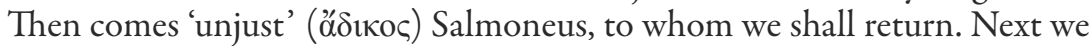
meet 'high-spirited' Perieres. Little is known of him; vं $x \hat{\varepsilon} \rho \theta v \mu \circ \varsigma$ ('high-spirited') has positive connotations often in the Iliad, but in the post-Homeric period largely carried the negative sense of 'overweening', used of monstrous, threatening forces, the byper-prefix marking transgressive excess. ${ }^{30}$ Deion and Magnes are similarly obscure, and their epithets are positive, if formulaic and unremarkable. The women are then described, positively, but in aesthetic rather than moral terms.

What is surprising, however, is the density of reference to theomachic activity - both in the Catalogue, so far as we can judge, and in later mythical reception of these figures. Consider the following (radically abbreviated) family tree, in which the divine figures are indicated by italics and the theomachic figures are highlighted in bold: ${ }^{31}$

29. Athamas killed his eldest son Learchus; he was the subject of plays by Aeschylus ( $\operatorname{Tr} G F$ 1-4a) and Sophocles (TrGF fr. 1-10). A curse on his house is mentioned by Herodotus 7.197.

30. Cf. Homer Od. 7.59 (of Eurymedon, king of the Giants); Hesiod Th. 719 (of the Titans).

31. The early parts of the stemma are found in fr. 5 Most; the name of the nymph Orseis is found in ps.-Apollodorus Bibliotheca 1.7.3. 


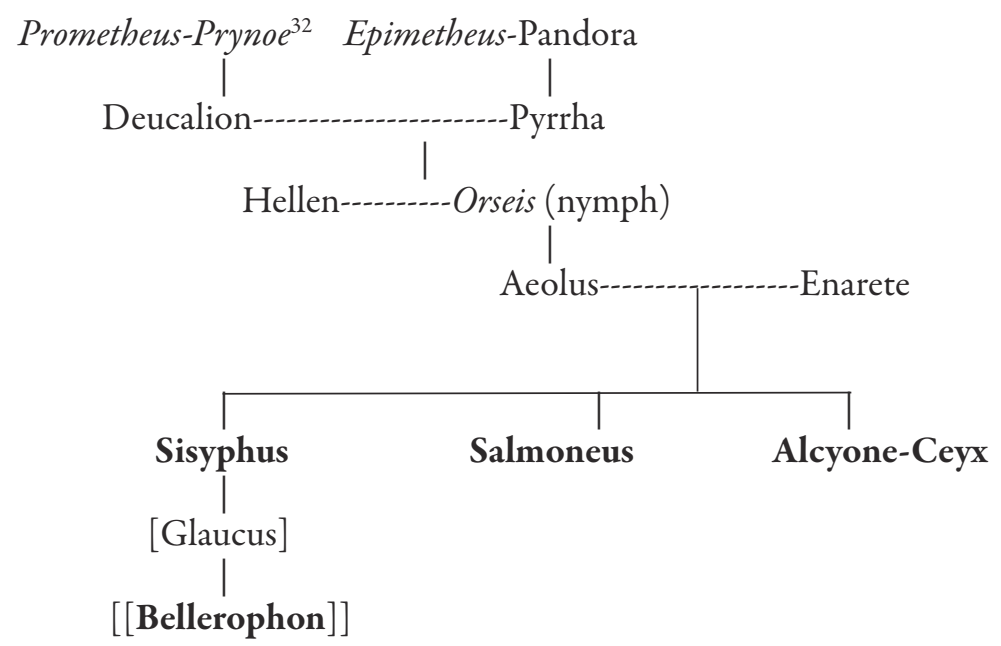

I have included Glaucus and Bellerophon out of completeness, since Glaucus is usually thought of as Sisyphus' son..$^{33}$ At least in the post-Homeric tradition, Bellerophon attempted an aerial assault on Olympus (using the winged horse Pegasus). In Euripides' Bellerophon, he apparently ${ }^{34}$ goes one stage further, putting forward an argument denying the existence of gods on the basis of the evidence for injustice in our world (an argument he may have found in the writings of Diagoras of Melos)..$^{35}$ The Catalogue, however, states that Sisyphus was denied a lineage by Zeus when he went in search of Eurynome's hand, and that Glaucus was in fact the son of Poseidon by the latter. $\mathrm{He}$ is thus part of the wider Aeolid narrative, but not (in the Catalogue) genetically connected to the family.

With Sisyphus, Salmoneus and Alcyone and Ceyx, however, we are on surer ground. ${ }^{36}$ We do not unfortunately have the Sisyphean episode in our surviving parts of the Catalogue, but there are two broad traditions that might explain the poet's adjective 'shifty-counseled': either he escaped from

32. The name Prynoe appears only in the Catalogue (fr. 5 Most); I have marked her as divine not with certainty but on the grounds that other progenitors in this generation are nymphs.

33. Homer Il. 6.153-154; ps.-Apollodorus Bibliotheca 1.9.3; cf. Pindar O. 13.61-64.

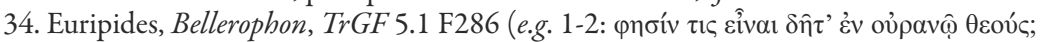

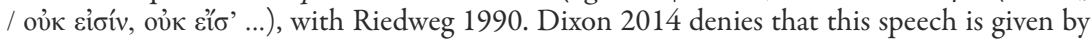
Bellerophon, but while his caution is welcome the evidence is tenuous.

35. For the possible link with Diagoras see Whitmarsh 2016.

36. There was also an archaic poem called The Wedding of Ceyx, associated in antiquity with Hesiod but sometimes denied to him (fr. 202-205 Most = 263-269 MW). Whether this was the same Ceyx is unclear from the scant fragments, which have a strong flavour of Heracles: Merkelbach and West 1965 and Cingano 2009: 125-126 think it is; D’Alessio 2005: 183-186 argues, plausibly to my mind, that we are dealing here with a different Ceyx. 
the underworld or he chained up Death to prevent humans dying. ${ }^{37}$ Either way, his crime is to erase the boundary separating mortals from immortals, and so to threaten the special status of gods. It is no doubt because of this mythical identity that the poet (Euripides or Critias) of the famous 'Sisyphus fragment', a dramatic excerpt (from a tragedy or a satyr play) arguing that gods are a human invention for the purposes of social control, put the argument in Sisyphus' mouth. ${ }^{38}$ Like Bellerophon, then, Sisyphus finds his implicitly atheistic behaviour in the Catalogue amplified with explicitly atheistic argumentation in fifth-century drama.

\section{Alcyone and Ceyx}

With Alcyone and Ceyx the ground becomes firmer still. This is a version different from Ovid's famous, romantic telling of the story. ${ }^{39}$ The relevant part of the Catalogue papyrus (fr. 10.86-98 Most) is broken at this point, but enough survives to confirm that Zeus transformed them into the birds that bear their names (the kingfisher and the tern) in punishment for their reckless behaviour. A papyrus fragment of a prose summary held in the University of Michigan fills out the full story:

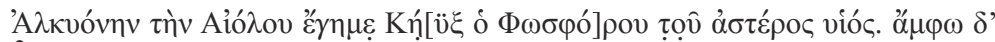

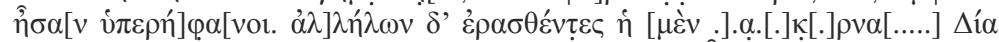

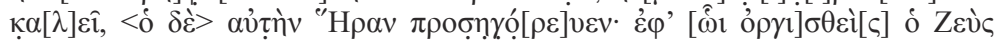

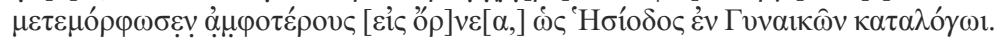

Ceyx the son of the star Phosphorus ('bringer of light') married Alcyone the daughter of Aeolus. The two of them were arrogant. They loved each other; she [...] called him Zeus, he named her Hera. Zeus was angered at this and metamorphosed them into birds, so says Hesiod in the Catalogue of Women. (fr. 12 Most $=$ P.Mich. inv. 1447 ii 14-19)

This account can be amplified by reference to two other versions of the story, from ps.-Apollodorus and the Etymologicum Genuinum, a 9th-century Byzantine compilation that compiles earlier material:

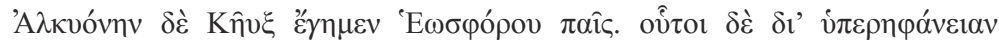

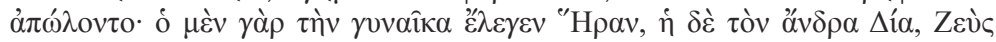

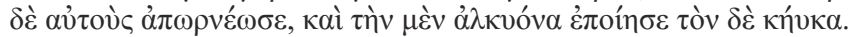

Ceyx the son of Eosphorus ('bringer of dawn') married Alcyone. They were destroyed for their arrogance. He called his wife Hera, she her husband Zeus. So Zeus made them into birds, transforming her into the 'kingfisher' (alkuone) and him into the 'tern' (keux)'. (ps.-Apollodorus, Bibliotheca 1.53)

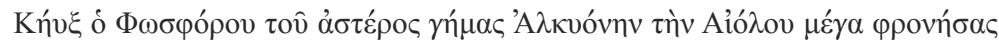

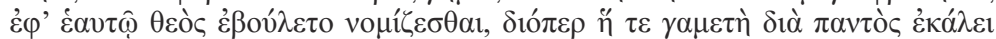

37. Nünlist 2006 has the details.

38. $\operatorname{Tr} G F 1$ (43) F 19 = B 25 DK. See most recently Davies 1989, Pechstein 1998, O'Sullivan 2011-2012, Sedley 2013b and Whitmarsh 2014.

39. Ovid Met. 11.410-748. On the evolution of the romantic version see Fantham 1979. 


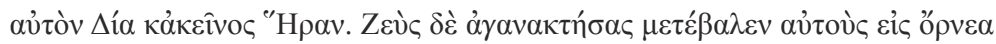

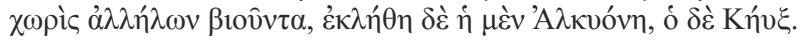

Ceyx the son of the star Phosphorus married Alcyone the daughter of Aeolus and got above himself and wanted to be thought of [or 'worshipped'?] as a god; for this reason his wife always called him Zeus and he called her Hera. Zeus became cross and turned them into birds who lived apart from each other. She was called Alcyone and he Ceyx. (Etymologicum Genuinum s.v. Alcyone)

The theomachic behaviour of Alcyone and Ceyx consists in their arrogation to themselves of the status of gods, and indeed of the names Hera and Zeus. The Michigan papyrus and ps.-Apollodorus describe this action with the terms i $\pi \varepsilon \rho \eta ́ \varphi \alpha v o \varsigma /$ i $\pi \varepsilon \rho \eta \varphi \alpha ́ v \varepsilon 1 \alpha$ ('arrogant' / 'arrogance'); the Byzantine lexicon, meanwhile, states that Ceyx 'got above himself', or lite-

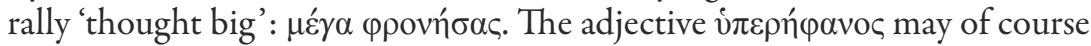
derive merely from the prose tradition, but there is a chance that it goes back to the Catalogue itself. We recall that the obscure Perieres was described with

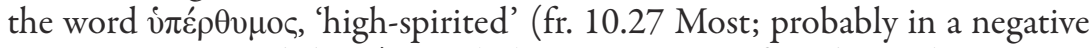
sense, as I suggested above). Similarly, i $\pi \varepsilon \rho n \varphi \alpha v o \varsigma$ is found in archaic poetry marking wanton behaviour. What exactly the element following the prefix means, however, is obscure. ${ }^{40}$ The hyper-prefix seems to point to excess, as in the parallel formation $i \pi \varepsilon \rho \eta ́ v \omega \rho$, 'over-manly' (i.e. manifesting an excess of masculinity). But the prefix also seems to suggest a desire to move 'above' one's station or 'beyond' proper boundaries. Homer's Nestor uses

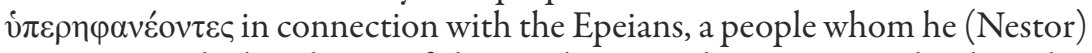
associates with the Eleians of the north-west Peloponnese, with whom his native Pylians have a dispute over cattle-rustling: presumably they are so described not simply because they are 'arrogant', but also because they transgress the Pylians' territorial boundaries and usurp their property. ${ }^{41}$ Hesiod uses $i \pi \varepsilon \rho n ́ \varphi \alpha v \alpha$ of the hundred-armed giants who help Zeus overthrow the Titans: here the word seems to suggest not so much transgression (the Giants are not usurpers in Hesiod) as superhuman size. ${ }^{42}$ In the archaic cases, then, i $\pi \varepsilon \rho n ́ \varphi \alpha v o c$ seems to refer both to a psychological or physical 'excess' characteristic of the individual or group, a latent potential for disruptive behaviour, and to the manifestation of that potential in specific acts of transgression, of going 'beyond' a stipulated sphere. ${ }^{43}$

40. Frisk 1970, Chantraine 2009 and Beekes 2009 s.v. are all equally at a loss. The least objectionable guess is a derivation from i $\pi \varepsilon \rho \varphi \varepsilon v$ ń, 'over-wealthy'. Chantraine considers any connection to $\varphi$ aívouar 'morphologiquement très peu plausible'.

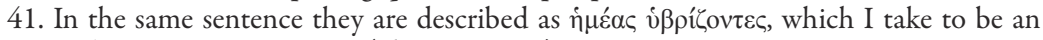
expansive gloss on i $\pi \varepsilon \rho \eta \varphi \alpha v \varepsilon ́ o v \tau \varepsilon \varsigma$ (Il. 11.693-695).

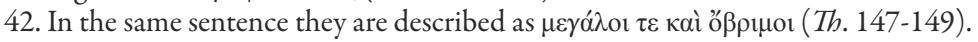

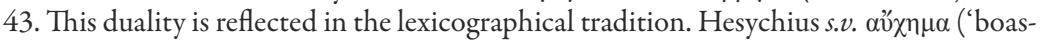

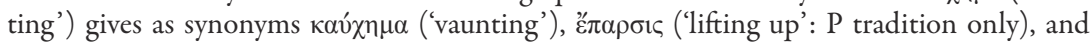


There may be additional connotations to the hyper-prefix. In the symbolic realm of myth, time and space are coordinated: the deep antiquity of the mythical past is correlated with the supreme physical elevation of the gods, whether they are imagined to be on Olympus or in the heavens themselves. 'Y $\pi \varepsilon \rho n ́ \varphi \alpha v o \varsigma$ may thus mark not simply a desire to go 'up', in spatial terms, to the realm of the divine. It may also suggest a movement back in time, to the period 'before' - to the era, I suggest, of commonality. For viźp as 'before', particularly 'before' some particularly decisive event, Liddell and Scott cite Thucydides' reference to the time 'before the Persian invasion'

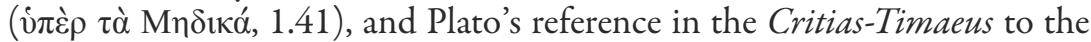

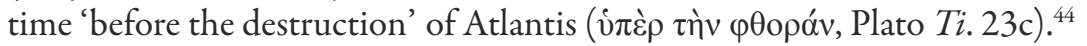

It is possible, then, that the crime of Alcyone and Ceyx lies only in part in their improper mental attitudes: ${ }^{45}$ they may also attempt to go 'beyond' mortality, and perhaps even 'back' to the age of commonality. This argument is, of course, doubly speculative, based as it is on both later prose summaries

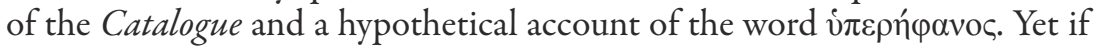
we look to the details of the story, we can begin to see how the $v \pi \varepsilon \rho \eta \varphi \alpha ́ v \varepsilon 1 \alpha$ of Alcyone and Ceyx might in fact have functioned as an attempt to lift them both 'upwards' to the celestial sphere and 'backwards' to the earlier era.

In the first place, they both manifest a genetic proximity to the divine. Alcyone is in the fourth generation since the separation of humans and gods; and more strikingly, Ceyx is the son of a star, the morning star (what we now call the planet Venus). The celestial origin of Ceyx is surely a factor integral to his $i \pi \varepsilon \rho \eta \varphi \alpha ́ v \varepsilon 1 \alpha$, his desire for elevation and return.

The second factor that elevates them is their mutual passion: 'they loved

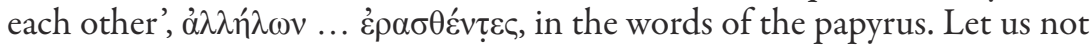
forget what a striking and unusual thing a passion between wife and husband was for early Greeks - odd enough, indeed, for Herodotus to single it out in the case of Candaules. ${ }^{46}$ In one of the legible passages of the papyrus, the poet of the Catalogue refers to a 'reckless love' ( $\mu \alpha \psi \alpha \delta$ ínı $\varphi 1 \lambda o ́ \tau \eta \tau \imath)$ between them. ${ }^{47}$ In this case, intriguingly, their erotic excess leads them to promote not themselves individually (as in, for example, the cases of Bellerophon and Sisyphus) but each other. The mirroring effect of their reciprocal desire leads to a mutually reflective narcissistic pact, whereby each is complicit in the other's superelevation. In time, as tastes and erotic protocols changed, the

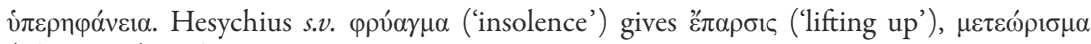
('elevation'), and í $\pi \varepsilon \rho \eta \varphi \alpha ́ v \varepsilon เ \alpha$.

44. $\operatorname{LSJ}$ (s.v. i $\pi \varepsilon ́ \rho \mathrm{IV})$.

45. At fr. 10.87 Most seems to suggest that they are 'damaged in their minds' (vóov $\beta \varepsilon \beta \lambda \alpha \mu \mu \varepsilon \varepsilon v$ [or (for the phrase with the genitive construction cf. Th. 223; Hirschberger 2004: 192).

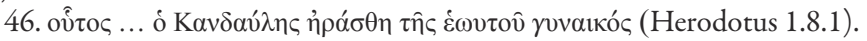

47. Fr. 10.87 Most. 
story of their mutual passion became a more positive one, eventually yielding the 'romantic' version of Ovid; but according to the archaic sensibilities reflected in the Catalogue, mutual love meant nothing more than a mutually reinforced self-deception, leading each falsely to affirm the other's divinity.

What is consistent across the three accounts cited above is the importance of naming. In each version, it is the erotically inspired act of appellation that seems directly to lead to the punishment: 'she [...] called him Zeus, he named her Hera. Zeus was angered at this and metamorphosed them into birds'; 'he called his wife Hera, she her husband Zeus. So Zeus made them into birds ...'; '... for this reason his wife always called him Zeus and he called her Hera. Zeus became cross and turned them into birds ...' At one level, naming is an act of performative (re)designation: since language is to an extent arbitrary, it is possible to bestow new names by fiat. And after all, is this not what lovers always do, giddy and exultant with the power to redesign the world so that all language reflects their passions? Viewed in this light, the vengeance exacted by Zeus becomes a form of linguistic policing, an insistent that verbal designations remain where they are. At the same time, however, Alcyone's and Ceyx' acts of verbal redesignation expose the fact that language is a cultural system, and that words are not bound to things by natural ligatures; they can indeed be reallocated by human agency. Can someone become a god, then, simply as a result of a wilful act of naming, born of desire? The Catalogue story suggests not, but Greek culture is in fact full of such acts of arbitrary designation. 'That man seems to me to be like a god', begins Sappho's most famous (and admittedly most opaque) poem. ${ }^{48}$ To experience one's beloved as godlike is, in early Greek thought, a natural function of desire. The story of Ceyx and Alcyone is ultimately about the perils of mutual obsession, especially in this in-between period when the worlds of gods and mortals are still crystallising into distinct units.

\section{Salmoneus}

Let us turn finally to Alcyone's brother, Salmoneus, king of Elis. In this case again we have a broken papyrus fragment of the Catalogue's account of his misdeed and punishment (fr. 27.2-23 Most), and later versions that are easier to read. Here is the version in ps.-Apollodorus:

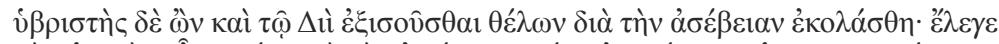

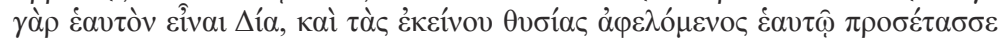

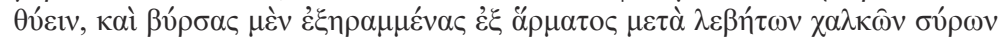

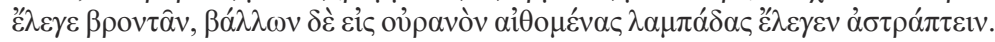

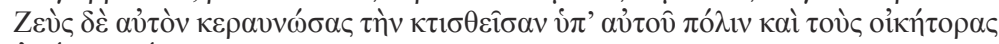

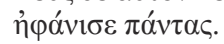


And being aggressive and wanting to put himself on an equality with Zeus, he was punished for his impiety; for he said that he was himself Zeus, and he took away the sacrifices of the god and ordered them to be offered to himself; and by dragging dried hides, with bronze kettles, at his chariot, he said that he was making thunder, and by flinging lighted torches at the sky he said that he lightened. But Zeus struck him with a thunderbolt, and wiped out the city he had founded with all its inhabitants. (Bibliotheca 1.89)

Like Alcyone and Ceyx, then, Salmoneus threatens Zeus' prerogatives by seeking to equate ( $\dot{\xi} \xi 1 \sigma 0 v \sigma \theta \alpha$ ) himself with the king of the gods. Salmoneus, however, goes one step further: if we are to believe ps.-Apollodorus (the lacunose Catalogue unfortunately contains no evidence for this), he actually denied Zeus sacrifice and claimed those rites for himself. Here then we see the fully theomachic implication of mortals acting as gods: to say 'I am [like] Zeus' is also, reciprocally, to say 'there is no Zeus but me'.

In the case of Salmoneus, again, the criticism focuses in part on his personal characteristics: we can read in the Catalogue papyrus that he is

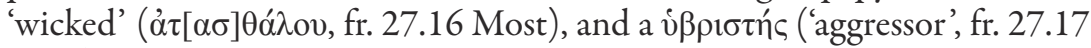
Most):

]v. ó $\delta ’ \dot{\alpha} \gamma \hat{\alpha} \tau[0 \pi \alpha \tau] \eta \grave{\rho} \rho \dot{\alpha} v \delta \rho \hat{\omega} v \tau \varepsilon \theta \varepsilon \hat{\omega} v \tau[\varepsilon$,

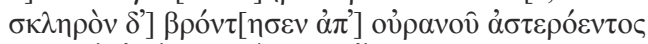

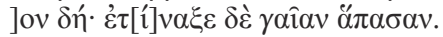

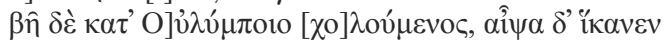

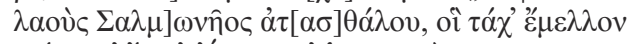

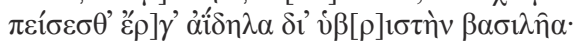

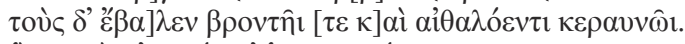

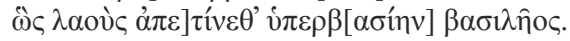

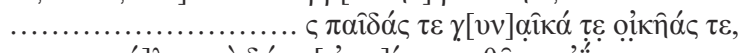

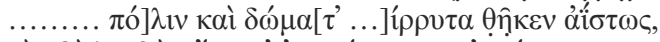

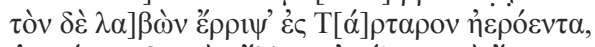

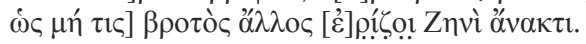

]. The [father] of men and of gods was angered,

and he thundered [hard from] the starry sky

]; he made the whole earth tremble.

He came down from] Olympus in anger, and at once he arrived among wicked Salmoneus' [people,] who were presently going

to suffer] destructive deeds because of their aggressive

king; he struck them] with thunder and blazing thunderbolt.

Thus he punished [the people] for their king's transgression.

] sons and wife and house-servants, ] city and [...]-flowing mansions,

he obliterated them, and seizing him he hurled him into murky Tartarus, so that no] other mortal would contend with lord Zeus.

(Cat. fr. 27.12-23 Most)

It is not simply, however, a matter of punishing Salmoneus for his character flaws. The Catalogue also refers to him as contending with Zeus

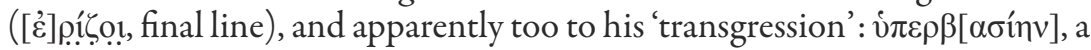
spatial metaphor that once again suggests going beyond or above the defined 
limit. In this case it is not erotic desire for the other but fascination with one's own political power that leads to the attempted elevation. Salmoneus is described in the Catalogue, in fact, not just as an 'aggressor' but as an 'aggressive king' ( $\dot{\beta}[\rho] \imath \sigma \tau \grave{v} v \beta \alpha \sigma \imath \lambda \hat{\eta} \alpha$ ); and it is not just with Zeus that he is contending, but (in the final line) 'Zeus the lord' (Znvi ơ $\alpha \alpha \kappa \tau \imath)$. These qualifications make it clear that Salmoneus' attempt to supplant Zeus is rooted in his own status as a monarch, and indeed in Zeus' too.

There are hints, too, that Salmoneus is being treated as a monstrous threat to Zeus' power, comparable to the Theogony's Titans. "Y $\beta \rho 1 \varsigma$ and $\alpha \tau \alpha \sigma \theta \alpha \lambda i \alpha$ are attributed to a range of figures in the Hesiodic and Homeric poems. ${ }^{49}$

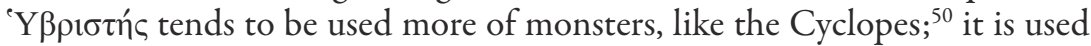
only twice in early epic of humans. ${ }^{51}$ What is more specifically titanic about Salmoneus is, in fact, Zeus' response to him: he blasts him with a thunderbolt, and sends him down to Tartarus. Compare the fate of Menoetius the Titan (the brother of Prometheus) in the Theogony:

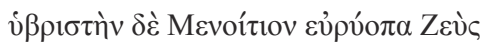

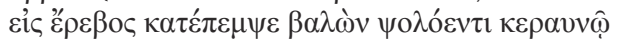

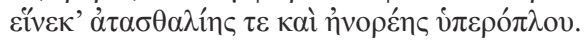

Zeus of the broad gaze cast down violent

Menoetius into Erebus, smiting him with the smouldering bolt

For his wickedness and overbearing manliness. (Th. 513-515)

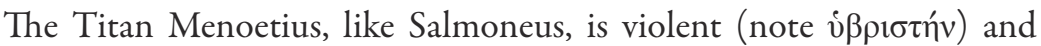
prone to wickedness ( $\dot{\alpha} \tau \alpha \sigma \theta \alpha \lambda i n \varsigma)$, and for this reason incinerated and sent down to the dark regions below. What is particularly striking about Salmoneus is that (in explicit contrast to his citizens) he is cast into Tartarus, a place that is otherwise reserved exclusively for malign immortals: it is there that Zeus threatens to hurl disobedient Olympians in the Iliad (8.13), and where the Titans themselves are imprisoned in the Theogony (721-725). Salmoneus' royal ambition, then, leads him to play a similar mythical role as the Titans who would seek literally to raise themselves into the sky, to elevate themselves to Olympus and to displace Zeus and the other gods. We should recall, indeed, that Salmoneus is not far removed from Titan blood: two of his great-great-grandfathers were of that brood. If it was love that drove Alcyone and Ceyx to see each other as gods, then, in Salmoneus' case it is a misplaced regal self-admiration.

Yet his challenge to Olympus is neither so forceful nor so impressive as that of the Titans; in fact it is rather comic. What is most striking about the

49. So e.g. the suitors in the Odyssey: Od. 1.34, 23.67 etc.

50. Od. 9.175; cf. 6.130, 13.201; compare Typhoeus (Hesiod Th. 307 and the snake at Cat. fr. 155.136 Most $=204.137$ MW).

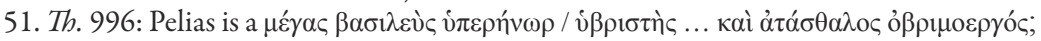
Homer $I l .13 .633$, of the Trojans. 
story is Salmoneus' use of household objects. Already in the Catalogue, he clearly attempts to replicate these mimetically, using pots and pans underneath his chariot for the noise and torches for the lightning. There is surely some delicate humour here: in particular, the use of kitchen utensils is an amusing touch (Greeks, after all, always found the appearance of kitchenware in supposedly 'high' poetry bathetic). ${ }^{52}$ These playful touches help to present him as a less than terrifying reviver of the Titanic tradition (and this was no doubt what attracted the attention of the writers of fifth-century satyr plays).

If, however, we attempt to read imaginatively along the grain of Salmoneus' own intentions, we may reconstruct a 'theory' of divinity as a constructed rather than a natural state: it is the product of cultural apparatuses, of embodied behaviour, or props, of language; it is reduced from a metaphysical distinction to a series of iconographic brand signifiers (thunder, lightning, the name). We can think of this 'theory' as an extension of Alcyone's and Ceyx' focus on language and naming as the source of divine authority; and indeed we are told by ps.-Apollodorus that 'he said that he himself was Zeus'

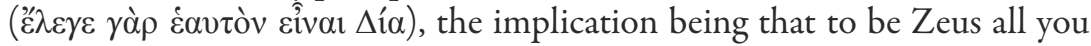
need to do is to replicate the brand markings.

In Diodorus of Sicily's version on the story, indeed, we find a heavy emphasis on the mechanistic manufacture of the thunder and lightning: 'Consequently he used to make a tremendous noise by means of a machine

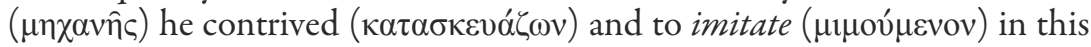
way peals of thunder..$^{53}$ Indeed, Salmoneus' crime is precisely mimetic: his crime is that he artificially replicates deity. It is striking, in this connection, how many of the relatively few mentions of Salmoneus in classical antiquity place the emphasis on mimesis and imitatio. ${ }^{54}$ These later accounts cannot, of course, be taken as a contextual frame for the interpretation of the Catalogue itself, but they do demonstrate that ancient readers too detected this mimetic aspect in the story.

Indeed, the mimetic connection may go even further than this. In a thought-provoking discussion, Stephen Trzaskoma and R. Scott Smith have observed that the kettles and hides suggest later descriptions of the bronteion, the theatrical device for replicating the sound of thunder, which (they believe) had its roots in pre-theatrical ritual practice..$^{55}$ To extend their claim, we might also point to the presence in the theatre (according, at

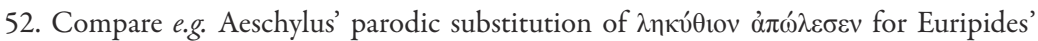
iambic line-endings at Aristophanes Ran. 1200-1246 (where Whitman 1969 also perceived an obscene pun).

53. Diodorus Siculus Bibl.Hist. 6.6.5.

54. Virgil Aen. 6.585-595 (imitatur ... imitabile ... simularet); Galen De Meth. Med.

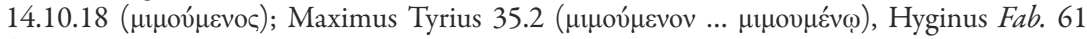
(imitaretur).

55. Trzaskoma and Scott Smith 2005. 
any rate, to the lexicographer of the second century CE Julius Pollux) of a keraunoskopeion, a device that produces the visual effects of theatre. ${ }^{56}$ If these (necessarily speculative) hypotheses are correct, then the Salmoneus story becomes a critique of the mimetic accompaniment to contemporary ritual practice.

Salmoneus' crime, then, is expressed via the adoption of artificial techniques that mimic the effects of divinity, techniques that may be rooted in forms of artistic, literary and ritual performance. The issue here, I submit, is an anxiety over the representation of the gods at the hands of humans. A proper cultural contextualisation is difficult given the issues of the dating and provenance of the Catalogue, but at the very least we can say that it belongs to the period of 150 years from the early seventh century to the late sixth, a period that saw at one end the introduction of colossal anthropoid statues of the gods, in imitation of Egyptian models and at the other end the inauguration of formalised theatre built around the display of the masked, disguised human body in the guise of a god. The fact that humans could themselves now create divinity was, to judge from the Salmoneus story (and to an extent the Alcyone story), a central theological problem. We might think, in this connection, of the celebrated critiques of anthropomorphism, composed by another hexameter poet of the same approximate period, Xenophanes. Consider this example:

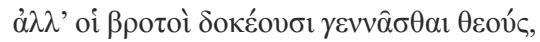

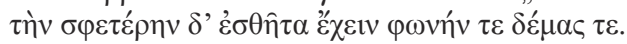

But mortals think gods are born, that they have human garb and voice and form. (Fr. D12 Laks-Most = B14 D-K)

Humans falsely believe, Xenophanes argues, that gods are identical to themselves. This belief, I propose, is the obverse of the Aeolid belief that one or one's beloved is identical to a god. In each case, the assimilation of human and god leads to an erasure of the conceptual distinctions between the two. Gods looks like mortals, mortals look like gods: at the level of appearance $\left(\delta \delta^{\prime} \xi \alpha\right)$, there is little to separate them.

Even more striking, for our purposes, is Xenophanes' direct association between anthropomorphic misidentification and artistic representation:

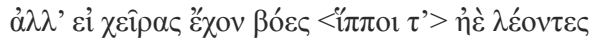

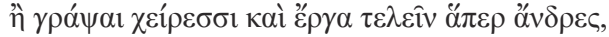

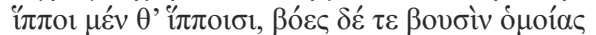

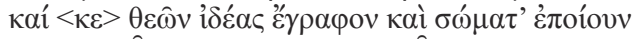

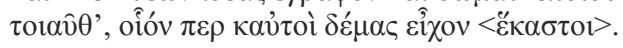

Now if horses or oxen or lions had hands

or the power to paint with hands and make the works of art

that men make,
} 
then would horses give their gods horse-like forms in painting or sculpture, and oxen ox-like forms, even each after its own

kind. (Fr. D14 Laks-Most = B15 D-K)

What is often overlooked in this fragment is that it is centrally about the power of visual depiction: it is through artistic representation that humans fix and disseminate their erroneous ideas about gods. The Catalogue's account of Salmoneus, I suggest, reflects the same anxieties over artistic representation as Xenophanes' critique. It does not, of course, tend towards the same conclusion: Xenophanes argues for the non-existence of Olympian deities on the grounds that they are mere mimetic fabrications, narcissistically devised by humans to mirror their own form; the Catalogue, by contrast, reasserts the existence of Olympian deities despite the attempts of humans to represent gods mimetically. But both are based in the same observation: that the capacity to depict deity through representation offers humans the possibility of generating gods in their own image, a possibility that challenges the idea of divinity as a distinct realm of existence.

\section{Conclusion}

The Catalogue of Women tells the story of the separation of humans and gods, of the age of commonality. Humans, however, at least in the interstitial phase described in the Catalogue, retain their links to the divine sphere, and in certain psychological states - when in love, or when consumed by royal self-belief - can imagine themselves returning to that state of proximity to the divine. All humans are, after all, ultimately descendants of Titans. ${ }^{57}$ But the Catalogue is more than just a reflex expression of primal mythology. It is also a sophisticated response to the theological concerns of archaic society, and in particular to the emergence of new technologies of representing divinity, such as monumental sculpture, painting and proto-theatrical ritual. These issues cluster magnetically around the descendants of Aeolus, who seem particularly prone to challenging the boundary between human and god; and in the fifth century at least two of them (Sisyphus and Bellerophon) were given formal atheistic argumentation by dramatic poets. Whether the Aeolids were held (either by the Catalogue poet or prior tradition) to be distinctively theomachic (that is, more so than other families) is not clear as things stand; the uneven survival rates for different parts of the poem may have distorted our evidence. ${ }^{58}$ What is more, if the answer is 'yes', then

57. In later times, 'Orphics' may have retained this view of an essentially 'Titanic' nature to humanity, as an explanation for the fallibility of mortals: e.g. Plato $L g$. $701 \mathrm{~b}$-c. For a recent, sceptical view of the evidence, however, see Edmonds 2013: 296-391 (see, however, contra Yates 2004: 193-194).

58. Willink 1983, for example, argues that the sophist Prodicus (known for his irreligious views) was associated with the mythological Tantalus. 
the explanation for that is not obvious either. The central point, however, relates to the ideas explored in these stories. The Catalogue does not depict the Aeolids as philosophical atheists, for sure, but it does deploy them as narrative tools to explore contemporary questions about the 'constructedness' of divinity. In the final analysis, the poem sides with Zeus, whose intervention and reassertion of his power cancels any doubt in the matter. The journey towards that ultimate conclusion, however, is an enlightening one, and shows the Catalogue poet to be more sophisticated, and more closely attuned to contemporary debates, than many have thought. 


\section{BIBLIOGRAPHIE}

BeEkes, R. S. 2009 : Etymological Dictionary of Greek, with the assistance of Lucien van Beek, 2 vols, Leiden, 2009 (Leiden Indo-European Etymological Dictionary series, 10).

Bremmer, J. 2007 : « Atheism in Antiquity » dans M. Martin (éd.), The Cambridge Companion to Atheism, Cambridge, 2007, p. 11-26 (Cambridge Companions to Philosophy).

Cancik-Lindemaier, H. 2006 : «Gottlosigkeit im Altertum : Materialismus, Pantheismus, Religionskritik, Atheismus », dans R. Faber \& S. Lanwerd (éd.), Atheismus: Ideologie, Philosophie oder Mentalität?, Würzburg, 2006, p. 15-33.

Chantraine, P. 2009 : Dictionnaire étymologique de la langue grecque, achevé par Jean Taillardat, Olivier Masson et Jean-Louis Perpillou, avec en supplément les Chroniques d'étymologie grecque (1-10) rassemblées par Alain Blanc, Charles de Lamberterie et Jean-Louis Perpillou, Paris, 2009 (Librairie Klincksieck. Série linguistique, 20).

Cingano, E. 2009 : « The Hesiodic Corpus » dans F. Montanari, A. Rengako \& C. Tsagalis (éd.), Brill's Companion to Hesiod, Leiden, 2009, p. 91-130.

Clay, J. S. 2003 : Hesiod's Cosmos, Cambridge, 2003.

D'Alessio, G. B. 2005 : «The Megalai Ehoiai: A Survey of the Fragments » dans R. L. Hunter (éd.) 2005, p. 176-216.

Davies, M. 1989 : « Sisyphus and the Invention of Religion ('Critias' TrGF 1 (43) F $19=$ B 25 DK) », BICS, 36/1 (1989), p. 16-32.

DeCharme, P. 1904 : La critique des traditions religieuses chez les Grecs : des origines au temps de Plutarque, Paris, 1904.

Descola, P. 2013 : Beyond Nature and Culture, trad. par J. Lloyd, préface de D. Marshall, Chicago, 2013.

Dixon, D. W. 2014 : «Reconsidering Euripides'Bellerophon », CQ, N. S. 64/2 (2014), p. 493-506.

Dorival, G. and D. Pralon 2002 (éd.) : Nier les dieux, nier Dieu : actes du colloque organisé par le Centre Paul-Albert Février (UMR 6125) à la Maison Méditerranéenne des Sciences de l'Homme les $1^{\text {er }}$ et 2 avril 1999, Aix-en-Provence, 2002 (Textes et documents de la Méditerranée antique et médiévale, 2).

Drachmann, A. 1922 : Atheism in Pagan Antiquity, London / Copenhagen / Christiania, 1922.

Edmonds, R. G. III 2013 : Redefining Ancient Orphism : A Study in Greek Religion, Cambridge, 2013.

Eidinow, E., J. Kindt \& R. Osborne 2016 (éd.) : Theologies of Ancient Greek Religion, Cambridge, 2016 (Cambridge Classical Studies).

Fantham, E. 1979: « Ovid's Ceyx and Alcyone: The Metamorphosis of a Myth », Phoenix, 33/4 (1979), p. 330-345.

Fisher, N. R. E. 1992 : Hybris : A Study in the Values of Honour and Shame in Ancient Greece, Warminster, 1992.

Ford, A. L. 1992 : Homer: The Poetry of the Past, Ithaca, 1992.

Fowler, R. L. 1999 : « Genealogical Thinking: Hesiod's Catalogue and the Creation of the Hellenes », PCPS, 44 (1999), p. 1-19. 
— 2011: « Mythos and Logos », JHS, 131 (2011), p. 45-66.

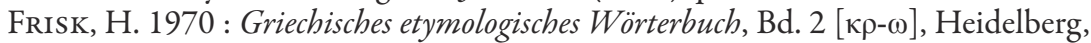
1970 (Indogermanische Bibliothek, II Reihe, Wörterbücher).

Hainsworth, J. B. A. 1988 : « Books V-VIII » dans A. Heubeck, S. West \& J. B A. Hainsworth, A Commentary on Homer's Odyssey, vol. I, Introduction and Books I-VIII, Oxford, 1988, p. 249-386.

Hirschberger, M. 2004 : Gynaikon Katalogos und Megalai Ehoai : Ein Kommentar zu den Fragmenten zweier hesiodeischer Epen, München, 2004 (Beiträge zur Altertumskunde, 198).

Hunter, R. L. 2005 (éd.) : The Hesiodic Catalogue of Women : Constructions and Reconstructions, Cambridge, 2005.

Janko, R. 1982 : Homer, Hesiod and the Hymns : Diachronic Development in Epic Diction, Cambridge, 1982 (Cambridge Classical Studies).

Ley, H. 1966 : Geschichte der Aufklärung und des Atheismus, Bd 1, Berlin, 1966.

Lloyd, G. E. R. 1990 : Demystifying Mentalities, Cambridge, 1990 (Themes in the Social Sciences).

Merkelbach, R. \& M. L. West 1965 : «The Wedding of Ceyx », RhM, 108 (1965), p. 300-317.

- 1967 (éd.) : Hesiod, Fragmenta Hesiodea, Oxford, 1967.

— 1990 (éd.) : Hesiod, « Fragmenta Selecta », dans F. Solmsen, Hesiodi Theogonia, Opera et Dies, Scutum, Oxford, 1990 [3 éd.], p. 111-226 (Scriptorum classicorum bibliotheca Oxoniensis).

Mikalson, J. D. 1991 : Honor Thy Gods : Popular Religion in Greek Tragedy, Chapel Hill, 1991.

Most, G. W. 2007 (éd.) : Hesiod, 1 : Theogony, Works and Days, Testimonia ; 2 : The Shield, Catalogue of Women, Other Fragments, Cambridge (Mass.), 2007 (The Loeb Classical Library, 503).

NüNLIST, R. 2006 : « Sisyphus » dans H. Cancik \& H. Schneider (éd.), Brill's New Pauly, vol. 13, Leiden, 2006, col. 510-511.

O'Sullivan, P. 2011-2012: « Sophistic Ethics, Old Atheism, and Critias on Religion », $C W, 105 / 2$ (2011-2012) p. 167-185.

PeCHSteIn, N. 1998 : Euripides Satyrographos: ein Kommentarzu den euripideischen Satyrspielfragmenten, Berlin, 1998 (Beiträge zur Altertumskunde, 115).

Riedweg, C. 1990 : « The "Atheistic" Fragment from Euripides' Bellerophontes $\left(286 \mathrm{~N}^{2}\right) \gg, I C S, 15 / 1$ (1990), p. 39-53.

Sedley, D. N. 2013a : « From the Pre-Socratics to the Hellenistic Age » dans S. Bullivant, \& M. Ruse (éd.), The Oxford Handbook of Atheism, Oxford, 2013, p. 139-151.

- 2013b : « The Atheist Underground » dans V. Harte \& M. Lane (éd.), Politeia in Greek and Roman Philosophy, Cambridge, 2013, p. 329-348.

Trzasкoma, S. \& R. Scotт Smith 2005 : «Apollodorus 1.9.7 : Salmoneus' Thunder Machine », Philologus, 149/2 (2005), p. 351-346.

Vernant, J.-P. 1983 : Myth and Thought Among the Greeks, London, 1983.

- 1989 : «At Man's Table : Hesiod's Foundation Myth of Sacrifice » dans M. Detienne \& J.-P. Vernant, The Cuisine of Sacrifice among the Greeks, Chicago, p. 21-86. 
Versnel, H. S. 2011 : Coping with the Gods: Wayward Readings in Greek Theology, Leiden, 2011 (Religions in the Graeco-Roman world, 173).

Vidal-Naquet, P. 1970 : « Valeurs religieuses et mythiques de la terre et du sacrifice dans l'Odyssée », Annales (ESC), 25/5 (1970), p. 1278-1297.

Viveiros DE CASTRO, E. 2014 : Cannibal Metaphysics: for a post-structural anthropology, trad. P. Skafish, Minneapolis, 2014.

West, M. L. 1985 : The Hesiodic Catalogue of Women : its Nature, Structure, and Origins, Oxford, 1985.

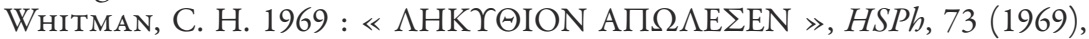
p. 109-112.

Whitmarsh, T. 2014 : «Atheist Aesthetics : The Sisyphus Fragment, Poetics and the Creativity of Drama », CCJ, 60 (2014), p. 109-126.

- 2015 : Battling the Gods: Atheism in the Ancient World, New York, 2015.

- 2016: «Diagoras, Bellerophon and the Siege of Olympus », JHS 136 (2016), p. $182-186$.

Willink, C. W. 1983 : « Prodikos, "Meteorosophists" and the "Tantalos" Paradigm », CQ, 33/1 (1983), p. 25-33.

Yates, V. 2004 : «The Titanic Origin of Humans : The Melian Nymphs and Zagreus », GRBS, 44/2 (2004), p. 183-198.

YU, K. W. 2017 : «From Mythos to Logos : Jean-Pierre Vernant, Max Weber and the Narrative of Occidental Rationalization », Modern Intellectual History, 14/2 (2017), p. 477-506 (published online sept. 2015 doi :10.1017/ S1479244315000323). 